\title{
THE INFLUENCE OF SERVICE QUALITY, CORPORATE IMAGE AND INTEREST RATE TO CUSTOMER PURCHASE OF MICRO CREDIT
}

\author{
Hengki Mangiring Parulian Simarmata ${ }^{1}$ \\ ${ }^{1}$ Politeknik Bisnis Indonesia \\ Hengkisimarmata.mm@gmail.com
}

\begin{abstract}
This study was aimed to determine the effect of service quality, corporate image and credit interest rates to the decision-making of micro credit case studies in Bank Prekreditan Rakyat Karyajatnika Sadaya (BPR KS) Bandung. Research was conducted using a descriptive and verivication studies. The samples used were 110 customers of the eight micro branches of BPR KS in Bandung. Hypothesis test using Structural Equation Model (SEM) to determine the effect of service quality, corporate image and credit interest rates on microcredit decision-either partially or simultaneously. The results showed that the quality of services rated as good by the respondent, BPR KS image is also considered to be good by the consumer. Meanwhile the interest rate offered is low or deemed reasonable by consumer. The result of model testing showed a positive and significant effect between service quality and corporate image of the micro-credit retrieval, while interest rates have a negative effect on the development of decision-making on micro credit. For subsequent researchers can conduct the same research in the different area of environment and cultures characteristics or by changing the variables where loyalty and customer relationship management variables can be developed in future research models.
\end{abstract}

Keywords: Service Quality, Corporate Image, Interest Rate, Consumer Decision Making

JEL : (Look at JEL Classification List)

DOI

Received:

Reviewed:

Final Version: 


\section{INTRODUCTION}

Banking has a very important role in the economic growth of a nation because of its role in financial services is able to drive the nation's economy. The development of financial institutions become a marker for the world corporate needs of financial and capital services. Public capital raised came from individuals or financial institutions such as commercial banks, Islamic Bank, Rural Banks (BPR), Pegadaian and Cooperation. BPR is an official banking institutions regulated by Law No. 7 of 1992 concerning Banking and as amended by Law No. 10 of 1998 (www.bi.go.id, 2013).

Currently, BPR development is not as smooth as it's been expected, in line with fierce competition in banking world and the various policies issued by Bank Indonesia to micro lending, BPR needs to work hard to compete and improve its business activities (www.infobanknews.com , 2013). According to data from Bank Indonesia and the Central Bureau of Statistics, the number of commercial bank branches developments in West Java are 392 offices, 27 Syariah Bank, 793 rural banks and 23.848 cooperatives comprising 589 KUD (Rural Unit Cooperation) and 23.259 non KUD (www.bi.go.id, 2013; BPS, 2013:417).

\section{Table 1.Number of Conventional Rural Bank (BPR) Based on Corporation in West J ava Province (2009-2013)}

\begin{tabular}{|c|c|}
\hline Year & Number of BPR \\
\hline 2009 & 398 \\
\hline 2010 & 376 \\
\hline 2011 & 325 \\
\hline 2012 & 307 \\
\hline Juli 2013 & $\mathbf{3 0 5}$ \\
\hline
\end{tabular}

Resources : www.bi.go.id, Statistik Perbankan Indonesia Vo.11 No.7 Juni 2013

Data from Bank Indonesia each year indicate the number of BPR is sloping down. With the policy of Bank Indonesia (PBI) 14/22/PBI/2012 call Commercial Bank portfolio by $20 \%$ should be used for the financing of Small Business lead the BPR had to fight hard in order to compete.

When compared with the Commercial Bank, BPR is certainly not really good in terms of service quality, corporate image and interest rates. With BPR characteristics that have ease in lending the loan with principle of timely, targeted, and the number and closer to the people making the BPR still attract more customers.

Intense competition in the banking industry was forced companies to redesign the business and marketing strategies to maintain or improve competitive advantage (Putra, 2013:448). Service Company or bank service must recognize that in order to compete more effectively, banks must demonstrate superiority of their products (Putra, 2013:490), provide better quality of services so that the company will have greater chances for success (Kumar, 2013:3). Banks with the largest customer base and level of loyal customers will become the market leader in the banking industry (Kumar, 2013:1). 
Perceived service quality will be a competitive advantage to attract new customers and contribute to market share (Junaid - ul - Haq, Abrar \& Nasir 2013:246; Hasan et al, 2013:301). If the customer is satisfied then he would repurchase and buy more, recommend the products to others and be loyal to the brand (Andronikidis, 2009:6; Liu \& Chen, 2013:159) so that they are less aware of the price and have a good experience with the company (Junaid - ul - haq, Abrar \& Nasir, 2013:246).

Consumer evaluation process comes after knowing the image of the company (Lin \& Lu, 2010:17; Junaid - ul - Haq, Abrar \& Nasir, 2013:247) and plays an important role in influencing consumer behavior (Chattananon, et al, 2008:350; Rattanaphan , 2012:290).

Most consumers will evaluate the overall relationship with a company from the type of product or service being offered, because the image is the perception of the strength in consumer mind when hearing the name of the company. Good corporate image and credibility will give confidence to consumers or industrial buyers (Amini et al, 2012:197). Many researchers in the field of marketing had acknowledges that the company's image becomes the dominant factor in consumer purchase behavior (Weiwei, 2007: 57)

BPR Karyajatnika Sadaya as a BPR based in Bandung is being part of the competition in finding customers. The quality that was given still felt less by the client, employee responsiveness to customers considered to be less optimal, speed of service delivery is still very slow. BPR KS needs to improve the quality of services by increasing human resources and increasing the use of renewable technologies into BPR KS commitment to the customers. Meanwhile, the interest rate also a sensitive issue for customers, offering low interest become an attraction for the customers using a bank loan products. BPR is still considered to have a high interest compared with the Commercial Bank, Islamic Bank or Mortgage Brokers.

The image that has been developed with the company's performance and continuous promotion impact to the community when the customer wants to have microcredit loans. Strong corporate image will have added value compared to other banks. Society also considers that given the interest rate is high in BPR, it has become one of the considerations in deciding which bank customers will be chosen.

The decision of taking micro product in BPR KS micro influenced by several factors, both in terms of quality of service provided, the image of the company and interest rates offered by BPR KS to the public.

Based on the background above, we identify the research problem is whether the service quality, corporate image and interest rate influence to the decisionmaking on taking micro credit products in BPR KS Bandung.

\section{Research Problems}

Based on the description above, it can be identified the problem as follows:

1. Is there an effect of quality service toward the decision on taking microcredit product in BPR KS Bandung?

2. Is there an effect of corporate image toward the decision on taking microcredit product in BPR KS Bandung? 
3. Is there an effect of interest rate effect toward the decision on taking microcredit products in BPR KS Bandung?

4. Is there an effect of service quality, corporate image and interest rate toward the decision on taking microcredit products in BPR KS Bandung?

\section{Research Objectives}

In accordance with the problems identified, the objectives of this study are:

1. To know the effect of service quality toward the decision on taking microcredit products in BPR KS Bandung.

2. To know the effect of corporate image toward the decision on taking microcredit products in BPR KS Bandung.

3. To know the effect of the interest rate toward the decision on taking microcredit products in BPR KS Bandung.

4. To know the effect of service quality, corporate image and interest rate towards the decision on taking microcredit products in BPR KS Bandung.

\section{Usefulness of Research}

Having regard to the purpose of the study, the authors expect this study to provide benefits to authors and other parties theoretically and practically, namely:

1. Academic Usefullness

a. Academically, as a contribution to science, particularly marketing management through the application of knowledge acquired by the reality that occurs in particular the banking sector.

b. University, where the results of this study are expected to be useful as a source of documentation as well as a source of scientific information and references for other researchers who want to conduct similar research.

2. Practical Usefulness

a. Society, as an alternative solution that expands horizons in designing strategic marketing management in developing financial institutions such as BPR rural banks, cooperatives and other financial institutions.

b. BPR Karyajatnika Sadaya Institution, the goal of this study can add to the idea of thinking and input in management decisions of BPR KS Bandung in terms of development as well as improving the quality of services rendered, the image of a company that has been built and the loan interest rate offered.

\section{LITERATURE REVIEW}

\section{Quality Service Concept}

Service quality is a prerequisite for the survival and development of any company (Chinh \& Anh, 2008:28), because increasing the quality of service becomes an important strategy to gain success and survive in competition (Greetings, Shawky \& Nahas, 2013:179). Some definitions of service quality is taken 
from the literature and international journals. Definition service quality are described as follows.

Definition of Quality according to Kotler \& Keller (2012: G7) is an overall service quality features and characteristics of a product or service that is able to satisfy or fulfill desires. Yousapronpaiboon \& Johnson (2013:176) defined service quality as the difference between customer perceptions of the services offered by the company and their expectations about the offer of the services of the company. In contrast to Hasan, et al (2013:301) describes the quality of service is determined by the difference between the service provider and customer expectations about the performance and evaluation of service received by the customer. Some researchers explain the importance of the quality of services as the result of their research :

a. To survive and thrive in the competition (Rahman, Haque\& Kan, 2012:115; Junaid - ul -Haq, Abrar \& Nasir, 2013:245)

b. Increasing consumer purchasing intentions (Hasan, et al, 2013:301; Rahman, Haque \&Kan, 2012:115; Junaid-ul-Haq, Abrar \& Nasir, 2013:246)

c. Maintaining long-term relationships with consumers (Junaid-ul-Haq, Abrar \& Nasir, 2013:245)

d. Increase customer satisfaction and loyalty (Mittal \& Gera, 2012:147; Liu \& Chen, 2013:158) e. Getting new customers (Junaid - ul - Haq, Abrar \& Nasir, 2013:246)

e. Get the new costumer (Junaid - ul - haq, Abrar \& Nasir, 2013:246)

f. Withstand price competition (Chinh \& Anh, 2008:28)

g. Improve corporate image (Ladhari, Ladhari \& Morales, 2010:224) h. Recommend word of-mouth (Lin \& Lu, 2010:22)

h. Increase profits (Andronikidis, 2009:5; Regards, Shawky \& Nahas, 2013:179)

i. Creating competitive advantage, differentiation and excellence business market (Kumar, 2013:1; Andronikidis, 2009:5; son, 2013:448)

This research defines service quality as an evaluation of service quality bank services received by the customer as a whole. Where the definition of service quality include the tangibles, reliability, responsiveness, assurance, and empathy which is a metric to determine the service quality of BPR KS Bandung.

\section{Corporate image Concept}

Corporate image has become an important strategy for many organizations in the improvement of performance and becoming a competitive advantage, according to Amini, et al (2012:192) states that the company who has a favorite image and strong brand equity can develop position in the company's market strategy

Definition of corporate image according to Hodović Babic, et al (2013:50) corporate image is defined as an overall evaluation of a company based on customer reaction to the company's products, services, communication activities, interaction with the company and / or representatives or constituencies (such as employees, management, or other customers) and / or activity of the company is known, while according to Junaid - ul - haq, Abrar \&Nasir (2013:246) corporate imagedefine as an intuition of the company in the customer's mind

Definition of corporate image in this research is the image of the company on customer assessment of BPR KS in the form of trust held by the bank, the reputation of performance will be known by the public as well as the knowledge of 
customers' bank logo, symbol and name of the company. Dimension ofcorporate imagethat will be used is Brand Personality, Organizational Assocation, Corporate Identity

\section{Price or Interest Rate Concept}

Putra (2013:490) describes the total price is a price that includes the cost, time, energy and physical cost incurred to evaluate, select, use or wear products of specific markets and Lovelock \& Wirtz (2011:622) price is something issued in the form of money, time and effort by consumers to buy or use the services.

Definition of interest rates by Kashmir (2005:152) that the bank rate can be interpreted as remuneration awarded on the basis of conventional banks to customers who buy or sell their products. The same thing also according to researchers Nasab \& Roomi (2012:1084) that bank's interest is defined as the price that must be paid to the customer (who has account) at a price to be paid by the customer to the bank (customers who obtain loans) as well as the prices charged to charges for other banks services.

Based on the definition of some experts, it can interprete that interest rate is the price paid by the customer for the funds/loan received from the bank. In measuring price or interest rate by modifying on the indicators that are tailored to the concept of the bank by using 3 items of question namely: the interest rate charged to new customers, interest rate is considered reasonable, the other bank interest rate

\section{Consumer Decision Making Concept}

According to Rahman, Haque \& Kan (2012:121), the purchase intention of consumers are based on consumer ratings reflected after evaluating to buy a product or service. While Lovelock \& Wirtz (2011:622) describes the process of purchasing as the degree to which consumers will choose, consume and evaluate a service and Lin \& Lu (2010:2) argues purchasing intentions as known behavior of certain exchanges made after evaluation of the consumer towards a product

According to Kotler and Keller (2012:188), consumer purchases will pass the 5 stages: problem recognition, information search, alternative evaluation, purchase decision and post purchase behavior.

Based on the concept of purchasing decisions which have described the measurement of purchasing decisions in this study adopted the indicator (a) Introduction to the problem: How important is the credit needs for customers, (b) Information retrieval: The extent to which credit information seeking from other banks (c) evaluation of alternative the extent to which the benefits when choosing BPR KS , (d) the purchase decision: the decision to choose or not to choose BPR KS.

\section{Research Framework}

Measurement of service quality is an important element to distinguish the extent BPR KS services compare with other competitors. High quality of services will be able to give contribution for corporate profits. Corporate image has become an important strategy for many organizations in the improvement of performance in the future and become a competitive advantage. Corporate image become a valuable asset that needs to be managed well by BPR KS. Price or interest rate defined its main purpose is to make a profit. However, companies should be careful lending 
rates offered are not too high as to make the customeris not interested and will disadvantage the company. Increasingly fierce competition makes prices more sensitive.

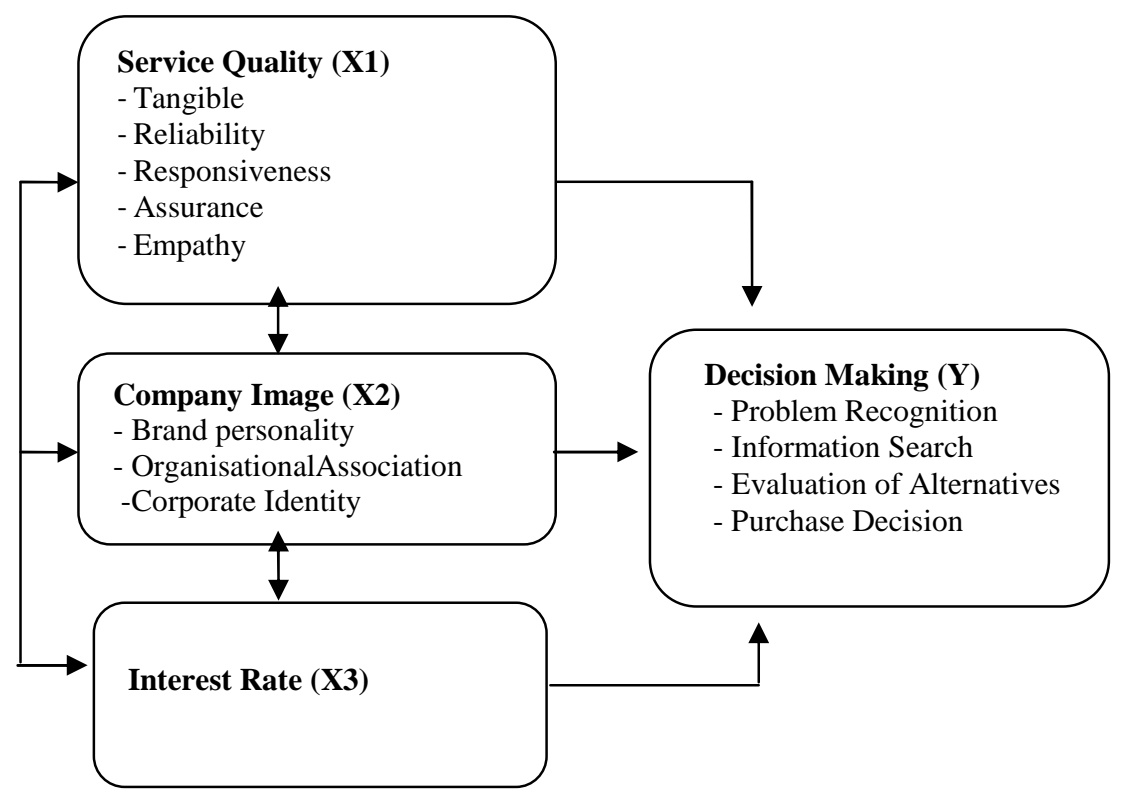

Figure 2 Paradigm ofResearch

\section{Hypothesis}

Based on the description above, the framework can be formulated in general research hypothesis as follows:

1. The higher of service quality in BPR KS, the higher the intensity of the customer to select the products micro BPR KS Bandung.

2. The better of corporate image, the higher the intensity of the customer to select the products micro BPR KS Bandung.

3. The lower of interest rate in BPR KS, the higher the intensity to choose products BPR KS micro Bandung.

4. There are influence between service quality, corporate image, and BPR KS interest rate toward the decision-making on taking microcredit in BPR KS Bandung.

\section{Research Methods}

The method used to determine the influence analysis of service quality, corporate image and the interest rate on the credit decision-making is descriptive method and verification method. Descriptive research on this study aims to gain an idea of the quality of services, the company's image, interest rates and thedecision making on taking micro credit product in BPR Karyajatnika Sadaya Bandung. Verification research is aims to understand the variables which affect and the variables which become the result and determine the nature of the relationship between the independent variables and the effect would be expected. 


\section{Data}

The primary data was obtained through data collection or getting information directly at the time of field research through interviews, observation and questionnaire survey using instruments. Minimum usable until a total of 110 people considered eligible. Questionnaire was distributed to 110 micro customers in eight branches BPR KS micro units in Bandung.

\section{Validity Test}

According to Sugiyono (2013:228) validity test performed using product moment correlation technique is used to calculate the correlation between each of the questions with a total score. Variable of service quality, corporate image, interest rate and the decision on taking the credit to be stated valid where the Pearson $r$ values greater than 0.3 so that the item of submitted questions for each variable were able to answer the theoretical question of service quality, corporate image, interest rates and decision on taking credit.

\section{Reliability Test}

This research implements the alpha Coefficient where Malhotra (2010:319). Cronbach Alpha test result value all items are reliable, the critical value> 0.7 Based on the reliability coefficient value then the dimension dimensions of service quality, corporate image, interest rate and decision on taking the credit is considered a reliable or create consistent results if repeated measurements was conducted to measure the relationship between variables.

\section{Analysis Design and Hypothesis Testing}

\section{Descriptive Analysis}

The data result from variable measurement is with ordinal values, so if we want to do statistical analysis then it must be scaled up into interval using the Method of Successive Intervals (MSI) (Ridwan \& Kuncoro, 2011:30)

\section{Verificative Analysis}

Verificative data analysis is used to answer research hypothesis by studying and relating between research variable. Verificative analysis conducted by using structural equation model or we can call it SEM (Structural Equation Model).

\section{Developing Theory Based Model}

2. Constructing Line Diagram for Causal Relation

3. Converting Line Diagram into structural model dan Measurement model

$$
\eta=\gamma_{1.1} \xi_{1}+\gamma_{1.2} \xi_{2}+\gamma_{1.3} \xi_{2}+\zeta_{1}
$$

4. Choosing Input Matrix and Model Estimation

5. Assessing Structural Model Identification

6. Match Evaluation Model based Goodness-of-fit Criteria Evaluasi

7. Model interpretation 


\section{Hypothesis Test}

\section{Partially (t-test)}

a. First Model hypothesis

$H_{0}: \gamma_{1.1}=0$ Service quality doesn't influence the decision on taking micro credit product in BPR KS Bandung

$\mathrm{Ha}: \gamma_{1.1} \neq 0$ Service quality influence the decision on taking micro credit product in BPR KS Bandung

b. Second Model hypothesis

$H_{0}: \gamma_{1.2}=0 \quad$ Corporate image doesn't influence the decision taking micro credit product in BPR KS Bandung

$\mathrm{Ha}: \gamma_{1.2} \neq 0$ Corporate image influence the decision on taking micro credit product in BPR KS Bandung

c. Third Model Hypothesis

$H_{0}: \gamma_{1.3}=0 \quad$ Interest rate doesn't influence the decision on taking micro credit product in BPR KS Bandung

$\mathrm{Ha}: \gamma_{1.3} \neq 0$ Interest rates influence the decision on taking micro credit product in BPR KS Bandung

Statistical test that is used $: t=\frac{\hat{\gamma}_{11}}{\operatorname{se}\left(\hat{\gamma}_{11}\right)}$

\section{Simultaneously (F-Test)}

a. Forth Hypothesis model

$$
\begin{aligned}
& \mathrm{H}_{0}: A l l \beta_{\mathrm{i}}=0 \quad \text { Service quality, corporate image and interest rate } \\
& \mathrm{i}=1,2,3 \text { simultaneously didn't affect on decision of taking micro } \\
& \text { credit product in BPR KS Bandung. }
\end{aligned}
$$

\section{Profile of Respondents}

Questionnaire data obtained from client of BPPR KS characterize by $69,1 \%$ of male respondent and only 34 or $30,9 \%$ female respondent with age characterictic less than 25 years $(15,55 \%)$, aged $25-35$ years $(41.8 \%)$, aged $36-45$ years $(31.8 \%)$, and age over 45 years $(10.9 \%)$. The data shows that the average age is dominated by age 25-35 years, while for the education profile, elementary education $(7.3 \%)$, junior high school (16.4\%), high school (47.3\%), Diploma 1/3 (15.5\%) and Bachelor $(12.7 \%)$. For monthly income, it can be seen that the customers who earn 2-4 million (37.3\%), 4-6 million (30.9\%), 6-8 million (20.9\%) and over 8 million (10.9\%).

From the results of the questionnaire data collection, we summarized the data of each variables indicators, each variable which has been studied will be outlined in the descriptive analysis using a continuous line described in Table 2 below. 
Table 2 Descriptive Analysis

\begin{tabular}{|l|c|c|c|c|}
\hline Variable & $\begin{array}{c}\text { Total } \\
\text { Score }\end{array}$ & $\begin{array}{c}\text { Percentage } \\
\text { Score }\end{array}$ & $\begin{array}{c}\text { Mean } \\
\text { Score }\end{array}$ & Category \\
\hline Service Quality & 399.00 & $72.54 \%$ & 3.626 & Good \\
\hline Corporate image & 395.33 & $71.87 \%$ & 3,59 & Good \\
\hline Interest Rate & 277.33 & $50.73 \%$ & 2.52 & Fair \\
\hline $\begin{array}{l}\text { Credit Decision } \\
\text { Making }\end{array}$ & 379.75 & $69.04 \%$ & 3.45 & Positive \\
\hline
\end{tabular}

\section{Verificative Analysis}

Normality Test Data. In the multivariate normality test, chi-square values obtained at 51.67 with a p-value of 0.000 , so $p$-value less than 0.05 can be explained that the data manifest variables (indicators) is not a multivariate normal distribution. Because the normality test results show that the data are not multivariate normal distribution, then as proposed by Raykov \& Marcoulides (2006: 30) when the data are not normally distributed, the estimation method used is robust maximum likelihood (RML).

The Result of goodness of fit model

According to goodness of fit test as Hair et al 2010 explain in (2013:49) that using of criteria is considered to be sufficient to a assess the feasibility of goodness of fit models, which Goodness of fit for this criteria (1) Absolute fit Indices (Root Mean Square Error of Approximation RMSEA have a good criteria with score 0.075), (2) to fit Incremental Indices (normed fit index NFI have a good criteria with score 0924, the Comparative fit Index CFI have a good criteria with score 0.969, $0.970 \mathrm{IFI}$ Incremental fit Indices of Relative fit Indices have a good criteria with and RFI have a good criteria with 0905).

Figure 1 Measurement Model

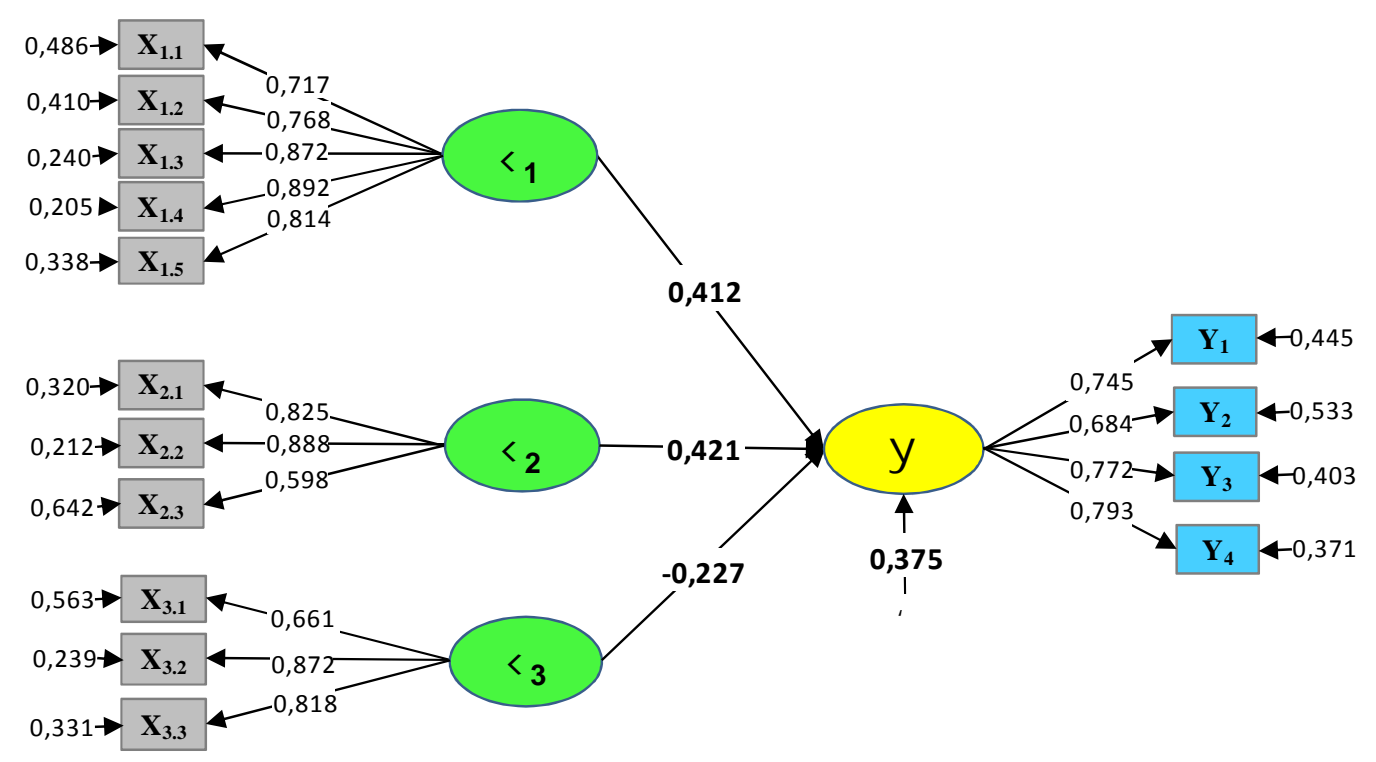


Table 3 Summary the result of Parameter Test on Variable Measurement Model

\begin{tabular}{|c|c|c|c|c|c|c|c|c|}
\hline Variable & $\begin{array}{c}\text { Dimentio } \\
\mathrm{n}\end{array}$ & $\begin{array}{l}\text { Weigh } \\
t \\
\text { Factor }\end{array}$ & $\begin{array}{c}\mathrm{t}^{\mathrm{c}} \\
\text { calculat } \\
\mathrm{e}^{-}\end{array}$ & $\begin{array}{c}\mathrm{t}- \\
\text { tabl } \\
\mathrm{e}\end{array}$ & $\begin{array}{c}\text { Explanatio } \\
n\end{array}$ & $\begin{array}{c}\text { Correlatio } \\
n \\
\text { Coefficient } \\
\left(\mathrm{R}^{2)}\right.\end{array}$ & $\begin{array}{c}\text { Composit } \\
e \\
\text { Reliability } \\
\text { (CR) }\end{array}$ & $\begin{array}{l}\text { Average } \\
\text { Variance } \\
\text { Extracte } \\
\text { d (AVE) }\end{array}$ \\
\hline \multirow{2}{*}{$\begin{array}{l}\text { Service } \\
\text { Quality }\end{array}$} & $\mathrm{X}_{1.4}$ & 0,892 & 33.89 & 1,96 & Significant & 0,795 & \multirow{2}{*}{0,908} & \multirow{2}{*}{0,665} \\
\hline & $\mathrm{X}_{1.3}$ & 0,872 & 30.06 & 1,96 & Significant & 0,760 & & \\
\hline $\begin{array}{l}\text { Corporat } \\
\text { e image }\end{array}$ & $\mathrm{X}_{2.2}$ & 0,888 & 20.99 & 1,96 & Significant & 0,788 & 0,820 & 0,609 \\
\hline $\begin{array}{l}\text { Interest } \\
\text { Rate }\end{array}$ & $X_{3.2}$ & 0,872 & 17.86 & 1,96 & Significant & 0,761 & 0,830 & 0,622 \\
\hline $\begin{array}{c}\text { Decision } \\
\text { on taking } \\
\text { credit }\end{array}$ & $Y_{4}$ & 0,793 & 11.85 & 1,96 & Significant & 0,629 & 0,838 & 0,562 \\
\hline
\end{tabular}

Based on the results of confirmatory factor analysis we can see the value weighting factor of each dimension is greater than 0.40 . The value of composite reliability (CR) is 0.908 for the quality of services, 0.820 for the corporate image, 0.830 for interest rate, and 0.838 for the decision on taking credits or overall greater than 0.70 indicates that all indicators have consistency in measuring service quality, image, interest rate and credit decision-making. Furthermore the value of average variance extracted (AVE) of information contained in each of the dimensions can be reflected through the latent variables of each variable.

Table 4 Summary of Statistical Test Result

\begin{tabular}{|c|c|r|r|c|}
\hline Tract & $\mathrm{t}_{\text {table }}$ & $\begin{array}{c}\mathrm{T}_{\text {calculat }} \\
\mathrm{e}^{*}\end{array}$ & Explanation & $\begin{array}{c}\text { Coefficient } \\
\text { Correlation } \\
\text { (R-Square) }\end{array}$ \\
\cline { 1 - 3 }$\xi_{1} \rightarrow \eta \eta$ & 0,412 & 4,446 & significance & \multirow{2}{*}{0,625} \\
\cline { 1 - 3 }$\xi_{2} \rightarrow \eta$ & 0,421 & 4,613 & significance & \\
\cline { 1 - 3 }$\xi_{3} \rightarrow \eta$ & $-0,227$ & $-2,641$ & significance & \\
\hline
\end{tabular}

The structural equation of service quality, corporate image and interest rate affect toward the decision of taking micro credit products can be formulated as follow :

$$
\begin{aligned}
& \eta=\gamma_{1.1} \xi_{1}+\gamma_{1.2} \xi_{2}+\gamma_{1.3} \xi_{2}+\zeta_{1} \\
& \eta=0.412^{\star} \xi_{1}+0.421^{\star} \xi_{2}-0.227^{\star} \xi_{3}, \text { Errorvar. }=0.375, R^{2}=0.625 \\
& \text { (0.0926) (0.0912) (0.0858) (0.0884) } \\
& \begin{array}{llll}
4.446 & 4.613 & -2.641 & 4.241
\end{array}
\end{aligned}
$$

From the result of data formulation summarize in table 4 , service quality, corporate image and interest rate altogether giving $62,5 \%$ of influence toward the 
decision on taking micro credit product in BPR KS Bandung, while the rest $(37,5 \%)$ is other factors which had not been observed.

Table 5 The Influence X1, X2 dan X3 variable Partially toward Y

\begin{tabular}{|c|c|c|c|c|c|}
\hline $\begin{array}{c}\text { Hypothesi } \\
\text { s }\end{array}$ & $\begin{array}{l}\text { Coefficien } \\
\mathrm{t} \text { Line }\end{array}$ & $\mathbf{T}_{\text {calculate }}$ & $T_{\text {table }}$ & Decision & Conclusion \\
\hline $\begin{array}{l}\text { Ho: } \rho y x_{1}=0 \\
\text { Ha: } \text { pyx }_{1} \neq 0\end{array}$ & 0,412 & 4,446 & 1,96 & $\begin{array}{c}\text { Ho rejected } \\
\text { and } \mathrm{Ha} \\
\text { accepted }\end{array}$ & Significant \\
\hline $\begin{array}{l}\text { Ho: } \text { pyx }_{2}=0 \\
\text { Ha: } \text { pyx }_{2} \neq 0\end{array}$ & 0,421 & 4,613 & 1,96 & $\begin{array}{c}\text { Ho rejected } \\
\text { and } \mathrm{Ha} \\
\text { accepted }\end{array}$ & Significant \\
\hline $\begin{array}{l}\text { Ho: } \text { pyx }_{3}=0 \\
\text { Ha: } \text { pyx }_{3} \neq 0\end{array}$ & $-0,227$ & $-2,641$ & 1,96 & $\begin{array}{c}\text { Ho rejected } \\
\text { and } \mathrm{Ha} \\
\text { accepted }\end{array}$ & Significant \\
\hline
\end{tabular}

According to test result we can see that the value of $t_{\text {calculate }}$ variableis larger than $t_{\text {table }}(1,96)$ Because of the value of $t_{\text {calculate }}$ is larger than $t_{\text {table }}$, so with $5 \%$ mistake rates, it can be decided to reject $\mathrm{Ho}$ so that $\mathrm{Ha}$ is accepted.

Table 6 Influence Inbetween Latent Variable

\begin{tabular}{|c|c|c|c|c|}
\hline \multirow{2}{*}{ Variable } & \multirow{2}{*}{$\begin{array}{l}\text { Coefficient } \\
\text { Line }\end{array}$} & \multicolumn{2}{|c|}{ Influence } & \multirow{2}{*}{$\begin{array}{l}\text { Total } \\
\text { Influence }\end{array}$} \\
\hline & & Direct & Indirect & \\
\hline Service Quality (X1) & 0.412 & $17.0 \%$ & & \\
\hline $\begin{array}{l}\text { Corporate image } \\
\text { (X2) }\end{array}$ & 0.421 & $17.7 \%$ & & \\
\hline Interest Rate (X3) & -0.227 & $5.2 \%$ & & \\
\hline $\mathrm{X} 1$ and $\mathrm{X} 2$ toward $\mathrm{Y}$ & 0.495 & & $24.3 \%$ & \\
\hline $\mathrm{X} 1$ and $\mathrm{X} 3$ toward $\mathrm{Y}$ & 0.427 & & $18.1 \%$ & \\
\hline$X 2$ and $X 3$ toward $Y$ & 0.452 & & $20.1 \%$ & \\
\hline $\begin{array}{l}\mathrm{X} 1, \mathrm{X} 2, \mathrm{X} 3 \text { teoward } \\
\mathrm{Y}\end{array}$ & & & & $62.5 \%$ \\
\hline $\begin{array}{l}\text { Influence of other } \\
\text { variable toward } Y()\end{array}$ & & & & $37.5 \%$ \\
\hline
\end{tabular}

a. The contribution of service quality to the decision of taking credit is $17.0 \%$. Therefore, to optimize the number of credits taken by customers, the service quality should be optimized. The findings of this study confirmed the statement by Junaid-ul-Haq, Abrar \& Nasir (2013:246) where the service quality will encourage customers to buy and use more services. The findings of this study are also supported by the opinion of Anh Chinh (2008:28) explains that the service quality 
is the key to long-term profitability because it affects the purchase intentions. This is also inline with the results of research conducted by Rahman, Haque \& Kan (2012) where the service quality have a significant positive influence in consumer decision making in choosing internet providers in Malaysia. Researched conducted by Oktarina (2011) in Bank Mandiri shows the influence of the perceived value of services to customers of 0:18 (or 18\%) and service delivery system that is given by Bank Mandiri Pondok Kelapa branch influence the client's decision to use the services of Bank Mandiri by 0:33 (or 33\%) which described the positive influence of service quality to the bank service usage decisions independently.

b. The contribution to corporate image to the decisionof taking credit is $17.7 \%$. Therefore, to optimize the number of credits taken by the customer that the corporate image should be optimized. This is consistent with the results of research conducted by Chattananon, et al (2008) that the brand development program has a positive impact on customers' purchase. Lin and Lu (2010) describes the results of his research in the absence of a significant effect of positive corporate image and purchase intention towards consumer. Researched conducted by Oktarina (2011) suggests that brand image owned by Bank Mandiri influence a client's decision to use the bank services indirectly through value of 0.276 or $(27.6 \%)$. From the study Oktarina (2011) we can conclude the existence of a significant and positive effect between brand image toward the decision to use Bank Mandiri service.

c. The contribution of interest rate in the decision of taking credit is $5.2 \%$. Therefore, to optimize the number of credit taken by the customer is that the rate of interest to be pay attention and not too high. Hypothesis test results explained that the higherof interest rates offered by the bank, the less of customer to take the credit. Thisresult was supported by the opinion of Lovelock \& Wirtz (2011:67) which state that the price is often a key factor in the purchase decision

\section{CONCLUSION}

1. The results illustrate that overall, BPR KS has provided good service to customers (total score of $72.54 \%$ ). The measurement of latent variables of service quality, dimensions X1.4 (assurance) and X1.3 (responsiveness) has the greatest weighting factors indicating that assurance and responsiveness become the most important part reflecting the latent variable of service quality. Service quality give a significant and positive effect on the decision-making on taking credit products. The contribution of service quality to the decision on taking micro credit is $17 \%$. Based on these results we can conclude the better the quality of the services can further improve retrieval micro credit in BPR KS Bandung.

2. BPR KS image is considered to be good according to consumer (total score of $71.87 \%$ ), Latent variable such as Organizational Assocation become the most influential factor in the formation of BPRKS image. Corporate image give positive and significant impact on the decision of taking credit products. The contribution of corporate imageaffect directly to the decision-making loans as much as $17.7 \%$. Based on these results it can be concluded that the better image of the company the more retrieval of microcredit in BPR KS Bandung.

3. Interest rate offered BPR KS can be considered sufficient or reasonable by the consumer. (total score of $50.73 \%$ ). The results of the measurement of interest rate 
latent variable, X3.2 indicator (desired interest rate) has the highest weighting factor which indicates that the interest rate indicator desired most important to be aware of. Interest rates negatively affect the decision-making on taking credit products. The contribution of interest rate directly to the decision-making of taking credit products is $5.2 \%$. Based on these results, it can be concluded that the lower the interest rate offered, it will improve the decision on taking microcredit in BPR $\mathrm{KS}$ and conversely, the higher the interest rate of the loan, the decision to take the credit will be decreased.

4. Quality Service, Corporate image and Interest rates simultaneously give a positive and significant impact on the decision-making of taking credit products. Service quality, Corporate image, Interest Rate contribute $62.5 \%$ of making the credit decision. There is a $37.5 \%$ influence on decision-making credit described by other variables outside quality services, corporate image and interest rate. The other factors that can be considered is costumer relationship management.

\subsection{Managerial Implication}

1. Company management or decision-makers in BPR KS need to make improvements on several aspects to boost credit growth. First, consider the quality of services as one of the most important factors of competitive advantage. By looking at the factors that influence the decision-making, the dominant element of the loan is expected to be considered and managed properly. Guarantee of service qualitycan be offered by creating a man power which is more friendly, polite, caring and able to communicate well with customers and improve the competence of staff in providing banking services. This can be improved with training and staff development, especially for the front liners. Evaluation of the quality of these services can be used to improve service quality continuously in BPR KS. The second things is to enhance thecorporate image, such as the trust and confidence in the minds of customers. BPR KS should be able to communicate those values to the public so that the experiences, feelings and ideas will be remembered by customers and transformed into positive sense that will be an effective media campaign for BPR KS to the public. Building a positive image can be done by communicating to the public that BPR KS microcredit product was superior compared to other banks, the quick process and simple requirements and build public confidence in the reputation of BPR KS as the biggest and most reliable BPR. Third, is the interest rate by knowing competitors interest rate and pay attention to changes in the interest rate environment either from commercial banks, rural banks or leasing. This is because the customer has sufficient knowledge of the level of interest rates and the interest rate is a sensitive issue for some customers, hence the need for understanding the characteristics of the customer as well as clear communication so that customers easily understand the interest rates that is offered.

2. In the future, the next researchers need to develop a study on microfinance institutions because of the lack of research on BPR compared to commercial banks. Study with the same variable against people who have different cultural environment, different social and economic situation might affect customers' perception on service quality. The study should not be limited to the quality of service, corporate image and interest rates, but also in customer relationship management that can influence the decision-making credit products. 


\section{REFERENCE}

Andronikidis, Andreas. 2009. Linking Dimensions of Perceived Service Quality to Actual Purchase Behavior. Vol. 4 No. 1, pp. 4-20. DOI10.1108/14502190910956666 www.emeraldinsight.com/1450-2194.htm.

Amini, Alireza., Mahdi Darani., Minoo Afshani., and Zahra Amini. 2012. Effectiveness of Marketing Strategies and Corporate Image on Brand Equity as a Sustainable Competitive Advantage. Interdisciplinary Journal Of Contemporary Research In Business. Vol. 4 No. 2, pp 192-205. ijcrb.webs.com.

Babić, Vesna Hodović., Maja Arslanagić., and Eldin Mehić. 2013. Importance of Internal Marketing for Service Companies Corporate Reputation and Customer Satisfaction. Journal of Business Administration Research. Vol. 2 No. 1, pp 4957. www.sciedu.ca/jbar.

Bank Indonesia, 1998. Undang-Undang Republik Indonesia Nomor 7 Tahun 1992 Tentang Perbankan sebagaimana telah diubah dengan Undang-Undang Nomor 10 Tahun 1998. Jakarta: Bank Indonesia.

Bank Indonesia, 2012. Peraturan Bank Indonesia Nomor 14/14/PBI/2012 tentang Tentang Pemberian kredit atau pembiayaan oleh Bank Umum dan Bantuan Teknis dalam Rangka Pengembangan Usaha Mikro, Kecil, dan Menegah. Jakarta : Bank Indonesia.

Bank Indonesia, 2012. Peraturan Bank Indonesia No.14/14/PBI/2012 tanggal 18 Oktober 2012 tentang Transparansi dan Publikasi Laporan Bank. Jakarta : Bank Indonesia.

Basuki, Eko Yanto. 1995. Hubungan Perhitungan Bianya Dana dengan Suku Bunga Pinjaman Kartu kredit Bank X. Bandung : Unpad Bandung.

Bravo, Rafael. and Jose M Pina. 2011. Communicating Spanish banks' identities: the role of websites. Online Information Review. Vol. 36 No. 5, pp. 675-697. www.emeraldinsight.com/1468-4527.htm.

Bravo, Rafael., Teresa Montaner., and Jose M Pina. 2012. Corporate brand image of financial institutions: a consumer approach. Journal of Product and Brand Management. Vol. 21 No. 4, pp 232-245. www.emeraldinsight.com/10610421.htm

Blomback, Anna. and Marcela Ramı́rez-Pasillas. 2012. Exploring the logics of corporate brand identity formation.Corporate Communications: An International Journal. Vol. 17 No. 1, pp 7-28. www.emeraldinsight.com/1356-3289.htm.

Barker. Chris, Nancy Pistrang \& Robert Elliot. 2002. Research Methods in Clinical Psychology. Second edition. John Wiley \& Sons, LTD Chichester England.

BPS. 2013. Jawa Barat Dalam Angka. Bandung : Badan Pusat Statistik Jawa Barat.

Chattananon, Apisit., Meredith Lawley., Numchai Supparerkchaisakul., and Lackana Leelayouthayothin. 2008. Impacts of a Thai cause-related marketing program on corporate image. International Journal of Emerging Markets. Vol. 3 No. 4, pp. 348-363 www.emeraldinsight.com/1746-8809.htm. 
Chattananon, Apisit., Meredith Lawley., Jirasek Trimetsoontorn., Numchai Supparerkchaisakul., and Lackana Leelayouthayothin. 2007. Building corporate image through societal marketing programs. Society and Business Review. Vol. 2 No. 3, pp. 230-253. www.emeraldinsight.com/1746-5680.htm.

Chinh, Vu Thi My. and Nguyen Viet Anh. 2008. Measuring Customer Satisfaction Base On Service Quality Gap At A Lokal Bank In Vietnam. Journal of International Business Research. Vol. 7 Special Issue. 3, pp. 27-50.

Coker, Anthonia., Jeremiah lyamabo., and Olutayo Otubanjo. 2013. Investigating Service Responsiveness in Customer Perception of the Corporate Logo. International Journal of Business and Management. Vol. 8 No. 11, pp 38-50 . http://dx.doi.org/10.5539/ijbm.v8n11p38.

Fitzsimmons, James A. and Mona J Fitzsimmons. 2011. Service Management : Operation, Strategy, Information Technology. Seventh Edition. New York : McGraw Hill.

Flavian, Carlos., Miguel Guinaliu., and Eduardo Torres. 2005. The Influence of Corporate Image On Consumer Trust : A Comparative Analysis in Traditional Versus Internet Banking. Vol. 15 No.4, pp 447-470. www.emeraldinsight.com/1066-2243.htm.

Hasan, Ameer., Usman Asif., Muhammad Irfan Arif., and Nimra Khan. 2013. ATM Service Quality and its Effect on Customer Retention: A Case from Pakistani Banks. Information Management and Business Review. Vol. 5 No. 6, pp. 300305 (ISSN 2220-3796).

Hasanudin, Mohamad dan Prihatiningsih. 2010. Analisis Pengaruh Dana Pihak ketiga, Tingkat Suku Bunga Kredit, Non Performance Loan (NPL), dan Tingkat Inflasi Terhadap Penyaluran Kredit Bank Perkreditan Rakyat (BPR) di Jawa Tengah. Semarang: Politeknik Negeri Semarang.Vol.5. No.1 p25-31.

Hair.Jr., JF., Anderson, R.E. Tatham, R.L., and Black, W.C., 2006. Multivariate Data Analysis. Fith Edition. Prince-Hall. Inc., New Jersy.

Herstein, Ram.,Yoram Mitki., and Eugene D. Jaffe. 2008. Corporate Image Reinforcement in an Era of Terrorism through Integrated Marketing Communication. Vol. 11 No. 4, pp 360-370. www.palgrave-journals.com/crr/.

Hosseini, Seyed Yaghoub., Manijeh Bahreini Zadeh., and Alireza Ziaei Bideh. 2013. Providing a Multidimensional Measurement Model for Assessing Mobile Telecommunication Service Quality (MS-Qual). Iranian Journal of Management Studies (IJMS). Vol. 6 No. 2, pp. 7-29.

Joseph F. Hair, Jr., William C. Black, Barry J.Babin, Rolph E. Anderson, Ronald L.Tatham, 2006.Multivariate Data Analysis. (sixth edition), Pearson Prentice Hall Education International.

Junaid-ul-haq, Muhammad Abrar. and Rao Umer Nasir. 2013. How Customer Loyalty Model Be Operative? A study of Cellular Phone Service Providers in Pakistan. Information Management and Business Review. Vol. 5 No. 5, pp. 245-256. ISSN 2220-3796

Kasmir. 2005. Pemasaran Bank. Jakarta : Kencana. 
Kumar, Anil. 2013. Constructing a Measurement in Service Q uality for Indian Banks: Structural Equation Modeling Approach. Journal of Internet Banking and Commerce. Vol. 18 No.1, pp 1-13 (http://www.arraydev.com/commerce/jibc/).

Kotler, Philip. and Kevin Lane Keller. 2012. Marketing Management. Fourteenth Edition. England: Printice Hall. page 188,198,332,396,405,408.

Ladhari, Riadh., Ines Ladhari., and Miguel Morales. 2010. Bank Service Quality : Comparing Canadian and Tunisian Customer Perceptions. International Journal of Bank Marketing. Vol. 29 No. 3, pp. 224-246. DOI 10.1108/02652321111117502 www.emeraldinsight.com/0265-2323.htm.

Leblanc, Gaston. and Nha Nguyen. 1996. Cues used by customers evaluating corporate image in service firms: an empirical study in financial institutions. The International Journal of Service Industry Management. Vol. 7 No. 2, pp 30-38.

Liu, Xilong. and Yizeng Chen. 2013. A FAHP-FUZZY Approach of Evaluating Banking Service Quality. International Journal of Business and Management. Vol. 8 No. 14, pp. 158-167. www.ccsenet.org/ijbm.

Lin, Long-Yi. and Ching-Yuh Lu. 2010. The influence of corporate image, relationship marketing, and trust on purchase intention: the moderating effects of word-ofmouth. Tourism Review. Vol. 65 No. 3, pp. 16-34. DOI 10.1108/16605371011083503.

Lovelock, Christopher. and Jochen Wirtz. 2011. Services Marketing, Strategy : People, Technology, Strategy. New Jersey : Prentice Hall. page $59,67,158,164,406,620,622$.

Malik, Muhammad Ehsan., Muhammad Mudasar Ghafoor., and Hafiz Kashif lqbal. 2012. Impact of Brand Image, Service Quality and price on customer satisfaction in Pakistan Telecommunication sector. International Journal of Business and Social Science. Vol. 3 No. 23, pp 123-129. www.ijbssnet.com.

Marković, Suzana., Sanja Raspor., Gordana Ivankovič., and Tanja Planinc. 2013. A study of expected and perceived service quality in Croatian and Slovenian hotel industry. European Journal of Tourism Research. Vol. 6 No. 1, pp 36-52.

Malhotra, Naresh K. 2010. Marketing Research : An Applied Orientation. Sixth Edition. New Jersey : Printice Hall.

Mittal, Sanjiv. and Rajat Gera. 2012. Relationship Between Service Quality Di Mensions And Behaviour Intentions : An Sem Study Of Public Sector Retail Banking Customers In India. Journal of Services Research. Vol. 12 No. 2, pp 147-171.

Misbach, Irwan., Surachman., Djumilah Hadiwidjojo., and Armanu. 2013. Islamic Bank Service Quality and Trust: Study on Islamic Bank in Makassar Indonesia. International Journal of Business and Management. Vol. 8 No. 5, pp 48-61. ISSN1833-3850 E-ISSN1833-8119. www.ccsenet.org/ijbm.

Mullins, John W et al. 2010. Marketing Management : A strategic Decision Making Approach. Seventh Edition. New York : McGraw-Hill.

Nasab, Ahmad Akbari. and Ali Savand Roomi. 2012. An Analysis Of Effective Factors On Bank Interest Margin Rate (Case Study: ANSAR BANK). 
Interdisciplinary Journal Of Contemporary Research In Business.Vol. 4 No. 2, pp 1084-1090. ijcrb.webs.com.

Nakhchian, Ali., Ome Kolsom Zeraatgar Boorani., and Nagres Groji. 2012. Overall profitability of companies depending on optimal use of the marketing mix (4Ps) (McDonald's case study). Interdisciplinary Journal of Contemporary Research In Business. Vol. 4 No. 7, pp 876-889.ijcrb.webs.com.

Oktarina, Uri. 2011. Persepsi Nasabah Tentang Sistem Penyampaian Jasa, Citra Merek dan Nilai Jasa Dalam Keputusan Penggunaan Jasa Bank Mandiri. Bandung : Unpad Bandung.

Parasuraman, A. 2010. Service productivity, quality and innovation. Implications for service-design practice and research. International Journal of Quality and Service Sciences. Vol. 2 No. 3, pp 277-286. www.emeraldinsight.com/1756669X.htm.

Putra, I Wayan Jaman Adi. 2013. The Effect Of Quality And Service Value On Customer Loyalty. A Study on the Customers of Commercial Banks in Malang City. Interdisciplinary Journal Of Contemporary Research In Business. Vol. 5 No. 5, pp. 488-504. ijcrb.webs.com.

Putera. Aria Bima Pertama. 2012. Analisis Faktor Atribut Produk dan Harga Terhadap Keputusan Pembelian Produk Mobile Broadband di Kota Bandung. Unpad Bandung.

Prince, Panuel Rozario. and Zumman Bin Khaleq. 2013. Assessment of Gap Between Service Quality Expectation and Perception: A Study on the Walk-In Guests of Economic Hotels in Cox's Bazar Bangladesh. The IUP Journal of Marketing Management, Vol. XII No. 3, pp 8-26.

Prihardianti, Andini. 2012. Analisis Pengaruh Kualitas Jasa dan Citra Perusahaan Terhadap Kepuasan Nasabah Pada Kantor Cabang Utama Bandung PT Bank Pembangunan Daerah Jawa Barat dan Banten Tbk. Bandung : Unpad Bandung.

Riduan. dan Engkos Achmad Kuncoro. 2011. Cara Menggunakan Dan Memakai Path Analysis. Bandung : Alfabeta

Rose, Peter S. and Sylvia C. Hudgins. 2010. Bank Management and Financial Service. Eight Edition. New York : McGraw-Hill.

Rahman, Muhammad Sabbir., Md Mahmudul Haque., and Abdul Highe Kan. 2012. A Conseptual Study on Consumers' Purchase Intention of Broadband Sevices : Service Quality and Experience E conomy Persperctive. International Journal of Business and Management. Vol. 7 No.18, pp 115-129. ISSN1833-3850 EISSN1833-8119. www.ccsenet.org/ijbm.

Rattanaphan, Prasit. 2012. Consumer Attitudes toward the Corporate Image of Direct Selling Companies in Thailand. International Journal of e-Education, eBusiness, e-Management and e-Learning. Vol. 2 No. 4, pp 290-293.

Raykov, Tenko and Marcoulides, George, A. 2006 "A First Course in Structural Equation Modeling" ( $2^{\text {nd }}$ ed), Lawrence Erlbaum Associates, Inc. New Jersey. 
Raychaudhuri, P S. and Rahela Farooqi. 2013. Conceptualization and Measurement of Service Quality Dimensions in Business Markets: A Case of Indian IT Industry. The IUP Journal of Management Research. Vol. XII No. 1, pp 33-61.

Salam, Eman Mohamed Abd-El., Ayman Yehia Shawky., and Tawfik El-Nahas. 2013. The impact of corporate image and reputation on service quality, customer satisfaction and customer loyalty: testing the mediating role. Case analysis in an international service company. The Business and Management Review. Vol.3 No.2, pp 177-196.

Skevin, Petra. 2011. Commercial Real Estate Marketing-The Importance Of Office Location On Corporate Image. Prethodno Priopćenje Preliminary Communication. Vol. XXIII br. 2, str 227-246.

Sugiyono. 2012. Metode Penelitian Kuantitatif dan RandD. Bandung : Alfabeta.

Sugiyono. 2013. Statistik Untuk Penelitian. Bandung : Alfabeta.

Tantawi, Passent. and Amr Youssef. 2012. The importance of corporate social performance in place branding of retail banks in Egypt. African Journal of Economic and Management Studies.Vol. 3 No. 1, pp. 77-94. www.emeraldinsight.com/2040-0705.htm.

Veerasamy, Dayaneethie., Jeevarathnam Parthasarathy Govender., And Magalingam Atheeshey Pillay. 2013. Service Quality in Sport: A Higher Education Perspective. Journal of Economics and Behavioral Studies. Vol. 5 No. 2, pp. 99-105. ISSN: 2220-6140.

Vegholm, Fatima. 2011. Relationship Marketing And The Management Of Corporate Image In The Bank -SME Relationship. Management Research Review. Vol. 34 No. 3, pp. 325-336. www.emeraldinsight.com/2040-8269.htm.

Weiwei, Tang. 2007. Impact Of Corporate Image And Corpirate Reputation On Customer Loyalty : A Review.Management Science and Engineering. Vol.1 No.2, pp 57-62.

Yousapronpaiboon, Khanchitpol. and William C Johnson. 2013. A Comparison of Service Quality between Private and Public Hospitals in Thailand. International Journal of Business and Social Science. Vol. 4 No. 11, pp 176-184. www.ijbssnet.com.

Zeithaml, Valarie A,. Mary Jo Bitner. and Dwayne D Gremler. 2009. Service Marketing : Integrating Customer Focus Across the Firm. Fifth Edition. New York : McGraw-Hill

Sumber Website:

BPRKS. 2013. Bank Perkreditan Rakyat Karya Jatnika Sadaya. Available at: http://www.bprks.co.id [Accessed 18 Februari 2013].

Bank Indonesia. 2013. Bank Indonesia. Available at: http://www.bi.go.id [Accessed 18 Februari 2013].

Bank Indonesia. 2013. Bank Indonesia Statistik BPR Sub Menu Kredit. Available at: http://www.bi.go.id/biweb/Templates/Statistik/Statistik\%20BPR/SubMenu Kredi t ID.aspx?NRMODE=Published\&NRNODEGUID=\{24475AE1-3B38-41E4- 
9F1B-

12B230B398F0\}\&NRORIGINALURL=\%2fweb\%2fid\%2fStatistik\%2fStatistik\%2 bPerbankan\%2fStatistik\%2bBPR\%2fKredit\%2f\&NRCACHEHINT=Guest [Accessed 20 Agustus 2013].

Bank Indonesia. 2013. Bank Indonesia Statistik BPR Sub Menu Kelembagaan Available at:

http://www.bi.go.id/biweb/Templates/Statistik/Statistik\%20BPR/SubMenu Kele mbagaan ID.aspx?NRMODE $=$ Published\&NRNODEGUID $=\{$ C0B82629-5AF9415A-AF2B-

DF34ED4A17B9\}\&NRORIGINALURL=\%2fweb\%2fid\%2fStatistik\%2fStatistik\%2 bPerbankan\%2fStatistik\%2bBPR\%2fKelembagaan\%2f\&NRCACHEHINT=Gues t [Accessed 20 Agustus 2013].

Bank Indonesia. 2014. Bank Indonesia Statistik Perbankan BPR Konvensional. Available at: http://www.bi.go.id/id/statistik/perbankan/bprkonvensional/totalaset/Default.aspx [Accessed februari 2014].

Infobanknews. 2013 BPR Harus Serius Agar Tidak salah Urus. Available at: http://www.infobanknews.com/2013/04/bpr-harus-serius-agar-tak-salah-urus/ [Accessed 14 September 2013].

Bisnis Jabar. 2013. BI Atur Persaingan BPR dan Bank Jateng. Available at: http://www.Bisnis-jabar.com/bi-atur-persaingan-bpr-bank-jateng.htm : [Accessed 18 Februari 2013].

Tempo. 2013. BPR Diminta Dilibatkan Dalam Penyaluran KUR. Available at: http://www.tempo.co/read/news/2010/11/23/087293786/BPR-Minta-DilibatkanDalam-Penyaluran-KUR [Accessed 18 februari 2013].

\section{Table result of Goodness of Fit model}

\begin{tabular}{|l|l|}
\hline $\begin{array}{c}\text { Measure of Goodness } \\
\text { of Fit }\end{array}$ & \multicolumn{1}{|c|}{ Estimation result } \\
\hline Chi-Square & $\begin{array}{l}135,02 \quad(p-v a l u e ~ \\
0,0004)\end{array}$ \\
\hline RMSEA & $0,075^{\star}$ \\
\hline GFI & 0,859 \\
\hline AGFI & 0,798 \\
\hline RMR & $0,064^{*}$ \\
\hline SRMR & $0,064^{*}$ \\
\hline NFI & $0,924^{\star}$ \\
\hline CFI & $0,969^{\star}$ \\
\hline IFI & $0,970^{\star}$ \\
\hline RFI & $0,905^{\star}$ \\
\hline
\end{tabular}

${ }^{*}$ received as a good model 